\title{
Aging Population as a Factor of Reduction of the Working-Age Population of the Country
}

\author{
Privalov Nikolai Gennadievich \\ Department of " Economic theory" \\ Emperor Alexander I St.Petersburg \\ State transport University \\ Saint Petersburg, Russia \\ ns-privalov@mail.ru
}

\author{
Zhuravleva Natalya Alexandrovna \\ Department of transport Economics \\ Emperor Alexander I St.Petersburg \\ State transport University \\ Saint Petersburg, Russia \\ zhuravleva_na@mail.ru
}

\author{
Privalova Svetlana Gennadievna \\ Department of transport Economics \\ Emperor Alexander I St.Petersburg \\ State transport University \\ Saint Petersburg, Russia \\ privalova-sg@inbox.ru
}

\begin{abstract}
The relevance of the article is that population ageing is one of the most important demographic problems that has a global character and affects all socio-economic processes of society. The article deals with the issues of demography, namely mortality and fertility, the change in total population, changes in age-sex structure and distribution of Russia's population between urban and rural areas for the period 2001 - 2018. We have separately studied the question of the ageing of the population. This problem is common to many modern economies. There are positive and negative consequences of this process. The main problem is the reduction of the working-age population of the country.
\end{abstract}

As effective methods of studying and analyzing phenomena and processes, the following are proposed: statistical observation, sampling; summary and grouping; a system of indicators (average, absolute and relative values, indices); graphical analysis, as well as own (special) research methods (scales-meters of demographic processes; sex and age pyramids; standardization; tables of survival; longitudinal and transverse analysis, etc.)

The analysis of demographic indicators of Russia allowed to carry out an assessment of features of sex and age structure of the population at the present stage and in the future. At the same time, the reduction of the working-age population of the country and the aging of the population were identified as the main trend. At the same time, migration processes, which include Russia, allow in recent years to "mitigate" the consequences of the growth of the coefficient of pension burden of the population.

All this requires the government to develop a set of measures to reduce the effects of demographic aging, maintain sustainable socio-economic development and ensure a decent quality of life for older people, as well as promote active old age, which implies maintaining productive employment of workers for longer periods.

Keywords: population, demographic problems, gender and age structure, population ageing, methods of regulation, demographic forecast, migration, migration processes

\section{INTRODUCTION}

The analysis of demographic processes of the last decades has shown: both in developed and developing countries the rate of population ageing has increased $[1,2,3,4,5]$

Population ageing is one of the most important demographic problems that has a global character and affects all socio-economic processes of society. The almost universal increase in the proportion of older persons is characterized by varying rates, which differ significantly across regions and countries $[2,3,4,5,6]$.

\section{A. Literature review}

Demography has been the focus of economic and statistical science since the eighteenth century. Having studied the theoretical aspects of population, we believe that all theories can be grouped into three historically established groups, depending on the factors affecting the change in the demographic situation:

- quantitative theories (reflect only the quantitative aspect of population changes). This theory of population: a) T. Malthus [7], explaining natural population growth natural and biological causes; b) $\mathrm{K}$ 
to consider these phenomena: a) in conjunction, with the aim of identifying the causal relationships of the development; b) dynamics, with the aim of establishing trends; C) comparing and mapping to determine the specificity of the object of study. As effective methods of studying and analyzing phenomena and processes, the following are proposed: statistical observation, sampling; summary and grouping; a system of indicators (average, absolute and relative values, indices); graphical analysis, as well as own (special) research methods (scales-meters of demographic processes; sex and age pyramids; standardization; tables of survival; longitudinal and transverse analysis, etc.).

The level and efficiency of management decision-making depend on the quality of the collected information, its relevance, reliability and completeness [24]. At the same time, of great practical importance are: assessment of population size and composition; study of population dynamics, its natural and migratory movement; assessment of population reproduction parameters; construction of forecasts.

\section{Methods AND MATERIALS}

In the dynamics of natural population change, the processes of fertility and mortality, marriage and divorce rates, migration, which have a direct impact on the birth rate, are considered. Thus, the population at the end of the year $\left(\mathrm{N}_{\mathrm{pe}}\right)$ is calculated on the basis of the following balance equation:

$$
N_{p e}=N_{p b}+B-D+A-L
$$
trends. However, due to the ideological orientation of the social Sciences in the USSR, which had a Marxist character, at first the theory of "demographic transition" acquired " its " features: a) initially, the three stages of the theory of transition reflected the specific types of the reproductive process of population (archetype, traditional type, rational) [15] (the transition from one stage to another ultimately depended on the productive forces development level); b) then (since 1982) - the four-phase model of "transition", based on qualitative indicators (fertility rates, mortality, the share of the workingage population, etc.), took into account their change in dynamics and "domestic national features" of filling these phases, which, in contrast to the global, "lagged" in time [16].

Modern studies of population aging processes have revealed: a) significant features of these processes in different countries of the world [17, 18, 19], highlighting Western European, Chinese, Russian, etc. [19]; b) these features are influenced by historical, geographical, political, socioeconomic, institutional and other factors [20, P. 235-251; 21, P. 925-942; 22, P. 210-222].

The broad discussion of global population growth and ageing has a great influence on the forecasting of economic fluctuations and the development of economic and social policies [23].

One of the instruments of regulation of socio-economic processes and phenomena is the monitoring and analysis of the main indicators characterizing them. The statistical learning processes serve the General scientific methods of cognition and General methods of the theory of statistics, which allow us where: $\mathrm{N}_{\mathrm{pb}}$ - population at the beginning of the year; $\mathrm{B}$ number of births; D - number of deaths; A - number of people arriving in the territory; $\mathrm{L}$ - number of people who left the territory.

The total change in population for the year $\left(\Delta \mathrm{N}_{\mathrm{tot}}\right)$ :

$$
\Delta N_{t o t}=N_{p e}-N_{p b}=(B-D)+(A-L)=P_{m i g}+P_{m i g}
$$

where: $P_{\text {nat }}$ - is the natural increase (decrease) of the population; $\mathrm{P}_{\mathrm{mig}}$ - migration (mechanical) increase (decrease) of population.

Foreign policy, domestic economic and social aspects of the government's policy are reflected not only in the life of society, but also in migration processes. Migration policy is increasingly influenced by factors related to the aging of the population.

The issues that reflect the causes and problems of the ageing of society are primarily related to the total load factor ( $\left.\mathrm{K}_{\text {tot.load fac. }}\right)$ and the coefficient of pension burden on the working population (pension load ratio) ( $\mathrm{K}_{\text {pens.load rat.), which }}$ are calculated accordingly:

$$
K_{\text {tot.load fac. }}=\left(P_{\text {youn.work. }} P_{\text {old.work }}\right) / P_{\text {work }}
$$




$$
K_{\text {pens.load rat. }}=P_{\text {old.work }} / P_{\text {work }}
$$

where: $\mathrm{P}_{\text {youn.work. }}$ - the population is younger than the working age (this includes men and women aged 0-15 years); $P_{\text {work. }}-$ the working-age population (men aged 16-59, women - 16-54 years) ; $\mathrm{P}_{\text {old.work. }}$ - population older than working age (formerly men aged 60 years and over, women aged 55 years and over; now men aged 65 years and over, women aged 60 years and over).

The forecast of demographic trends is one of the directions of analysis and evaluation of the population structure. The purpose of this forecast is to identify possible negative trends and management decisions at the international, state or regional levels. The most common method of forecasting in this case is a prospective calculation of the population, provided that the prevailing trends in fertility and mortality.

The only method that allows you to build a forecast not only the total number, but also the age and sex structure of the population, is the method shifting ages (component method). The following group of consequences of the current trends is considered $[25,26]$ :

Reduction of the total population and its labor potential. In this case, there is a decrease in the number of potential employees, and their age composition becomes older with obvious positive (experience, qualifications) and negative (conservatism, reduced initiative) consequences.

Changing the ratio of the main age groups of the population by reducing the proportion of children and adolescents and increasing the proportion of older people. This requires a fundamental restructuring of the social infrastructure to meet the needs of the elderly.

The lack of a mechanism for smoothing deformations of the age and sex structure of the population.

Fixing the imbalances of the population by sex, due to the high mortality of men of all age groups [5].

These effects allow us to quantify the method of movement of ages, the essence of which is to assess the movement of indicators over time on the basis of the specified forecast parameters of fertility, mortality and migration.

Method of shifting ages (method component): [27];

a) is believed to have been developed by Whelpton P. K.

b) calculations of the age structure of the population by this method worked in Russia and S. G. Strumilin, p. P. Shusharin, A. Y. Boyarsky, M. S. Poor, etc.; among foreign authors note V. Lutz, W. Sanderson, R. Lee [28], etc.;

c) is used by the population Commission of the United Nations;

d) officially applied the Federal state statistics service.

The method of movement of ages allows us to quantify these effects. The essence of this method is to assess the movement of indicators over time on the basis of the specified forecast parameters of fertility, mortality and migration.
Calculation scheme according to the method of shifting ages is:

a) known age structure of the population $S_{t x}$ at beginning of year $(\mathrm{t})$;

b) during the year there is a change in the baseline population: mortality, migration;

c) at beginning of year $(t+1)$ the population aged $(x+1)$ is determined by the formula:

$$
S_{x+1}^{t+1}=S_{x}^{t} \cdot P_{x}+M_{x}
$$

where: $P_{x}=L_{x}+\frac{1}{L_{x}}$ - the coefficient of movement in the next age, which is determined by the ratio of the number of living on the tables of survival at the age of $(x)$ and $(x+1) ; M_{x}$ - balance age-specific migration.

This procedure applies to all ages except 0 years of age. The number of this age group in the period $(t+1)$ is calculated taking into account the indicators of the birth rate and infant mortality. The number of births is calculated by multiplying the number of age-related births and the average annual number of women of the corresponding age. Age-related fertility is the result of a forecast of the nature of fertility in the future. The number of women is determined by the results of the preliminary survey. To calculate the number of boys and girls separately, the sex ratio at birth is used, which is an empirical pattern recorded over a long period of observation. Then multiplying the number of births by the probability of survival from the mortality tables for the population of the corresponding sex, the number $\mathrm{S}_{\mathrm{t}+10}$ is obtained. It should be noted that the procedure in question is carried out as many times as it is necessary to carry out the forecast for how many years ahead. At the same time, the population of each age moves to the next, older age $[25,26]$.

The theoretical basis for statistical analysis of the demographic situation in the country is a set of demographic, social, medical and economic indicators.

\section{RESULTS}

According to the Federal state statistics service of Russia, we analyzed the distribution of the country's population by territory of residence (city - village), sex and age structure and the ratio of births and deaths (figures 1 and 2, table I). 
trend. Examining these indicators from 1926 to the current

Growth rate

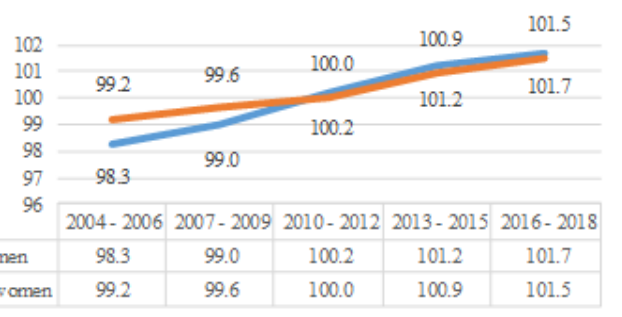

Fig. 1. The growth rate of the total number of men and women for the period 2004-2018

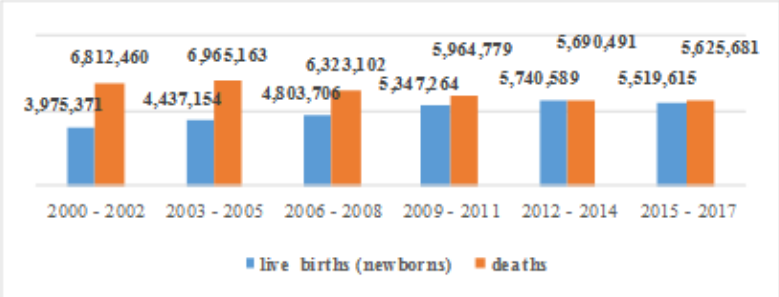

Fig. 2. The ratio of births and deaths in Russia from 2000 to 2017

TABLE I. THE POPULATION OF RUSSIA BY LEVEL OF URBANIZATION AND GENDER

\begin{tabular}{|c|c|c|c|c|c|c|c|c|c|}
\hline \multirow[t]{2}{*}{ Years } & \multirow{2}{*}{$\begin{array}{c}\text { Every- } \\
\text { thing } \\
\text { popu- } \\
\text { lation } \\
\text { (mln. } \\
\text { people) }\end{array}$} & \multicolumn{2}{|c|}{$\begin{array}{l}\text { Of the total } \\
\text { population (in } \\
\text { million } \\
\text { people) } \\
\end{array}$} & \multicolumn{2}{|c|}{$\begin{array}{c}\text { In the total } \\
\text { population } \\
(\%)\end{array}$} & \multicolumn{2}{|c|}{$\begin{array}{l}\text { Of the total } \\
\text { population } \\
\text { (in million } \\
\text { people) }\end{array}$} & \multicolumn{2}{|c|}{$\begin{array}{l}\text { In the total } \\
\text { population } \\
(\%)\end{array}$} \\
\hline & & citi & village & citi & village & men & women & men & $\begin{array}{l}\text { wo- } \\
\text { men }\end{array}$ \\
\hline 2001 & 146.3 & 107.1 & 39.2 & 73.21 & 26.79 & 68.3 & 78.0 & 46.68 & 53.32 \\
\hline 2002 & 145.2 & \begin{tabular}{|l|}
106.4 \\
\end{tabular} & 38.8 & 73.28 & 26.72 & 67.6 & 77.6 & 46.56 & 53.44 \\
\hline 2003 & 145.0 & 106.3 & 38.7 & 73.31 & 26.69 & 67.5 & 77.5 & 46.55 & 53.45 \\
\hline 2004 & 144.3 & \begin{tabular}{|l|}
106.0 \\
\end{tabular} & 38.3 & 73.46 & 26.54 & 67.0 & \begin{tabular}{|l|}
77.3 \\
\end{tabular} & 46.43 & 53.57 \\
\hline 2005 & 143.8 & 105.2 & 38.6 & 73.16 & 26.84 & 66.7 & 77.1 & 46.38 & 53.62 \\
\hline 2006 & 143.2 & 104.8 & 38.4 & 73.18 & 26.82 & 66.3 & 76.9 & 46.3 & 53.7 \\
\hline 2007 & 142.8 & 104.7 & 38.1 & 73.32 & 26.68 & 66.0 & 76.8 & 46.22 & 53.78 \\
\hline 2008 & 142. & 104.9 & 37.9 & 73.46 & 26.54 & 66.0 & 76. & 46.22 & 53.78 \\
\hline 2009 & 142.7 & 104.9 & 37.8 & 73.51 & 26.49 & 65.9 & 76.8 & 46.18 & 53.82 \\
\hline 2010 & 142.9 & 105.3 & 37.6 & 73.69 & 26.31 & 66.1 & 76.8 & 46.26 & 53.74 \\
\hline 2011 & 142.9 & \begin{tabular}{|l|}
105.4 \\
\end{tabular} & 37.5 & 73.76 & 26.24 & 66.1 & 76.8 & 46.26 & 53.74 \\
\hline 2012 & 143.0 & 105.7 & 37.3 & 73.92 & 26.08 & 66.1 & 76.9 & 46.22 & 53.78 \\
\hline 2013 & 143.3 & \begin{tabular}{|l|}
106.1 \\
\end{tabular} & 37.2 & 74.04 & 25.96 & 66.3 & 77.0 & 46.27 & 53.73 \\
\hline 2014 & 143.7 & 106.6 & 37.1 & 74.18 & 25.82 & 66.6 & 77.1 & 46.35 & 53.65 \\
\hline 2015 & 146.3 & \begin{tabular}{|l|}
108.3 \\
\end{tabular} & 38.0 & 74.03 & 25.97 & 67.8 & 78.5 & 46.34 & 53.66 \\
\hline 2016 & 146.5 & 108.6 & 37.9 & 74.13 & 25.87 & 67.9 & 78.6 & 46.35 & 53.65 \\
\hline 2017 & 146.8 & 109.0 & 37.8 & 74.25 & 25.75 & 68.1 & 78.7 & 46.39 & 53.61 \\
\hline 2018 & 146.9 & \begin{tabular}{|l|}
109.3 \\
\end{tabular} & 37.6 & 74.4 & 25.6 & 68.1 & 78.8 & 46.36 & 53.64 \\
\hline \multicolumn{4}{|c|}{18 years average } & 73.68 & 26.32 & & & 46.35 & 53.65 \\
\hline \multicolumn{10}{|c|}{${ }^{1}$ Constructed and calculated by the authors according to the Federal state statistics service $[3,4,6,25]$} \\
\hline
\end{tabular}

The analysis allows to draw the following conclusions:

1) Since the beginning of the XXI century, the dynamics of the population of the country as a whole is relatively stable the Decline of 2001-2014 since 2015 has turned into a positive date, we note the presence of cyclicality of this process (and in different periods: 18-22-year cycles). Since 2015, there has been a slight positive growth trend.

2) The relative symmetry of the pyramid, built according to the calculated average for 18 years of study indicators, for the age group from 0 to 50 years indicates slight differences in the number of men and women of this age, which indicates a relatively "quiet years" of our society and the economy as a whole. The most significant deviations are observed in the age group of 70 years and older with a significant difference between the number of men and women over the age of 80 years.

3) Throughout the study period, there is an annual decrease in the rural population with an increase in the share of the urban population. Slight fluctuations in the level of urbanization suggest that the main process of "Exodus of the village to the city" is basically over. However, the presence of a constant small increase in this indicator, on the one hand, characterizes the presence of the process of population flow into the city due to natural economic reasons, on the othercontinues to indicate a significant increase in differences in infrastructure, transport accessibility, social security, the availability of a network of roads, educational and cultural level, etc.

TABLE II. DISTRIBUTION OF POPULATION BY AGE GROUPS (\%).

\begin{tabular}{|c|c|c|c|c|c|c|c|c|c|c|c|c|}
\hline $\begin{array}{c}\text { Year } \\
\text { Indicators }\end{array}$ & ڤั & ฒิ & ڤू & న్ & ลิ & ळे & 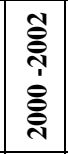 & 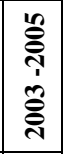 & 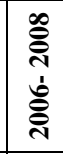 & 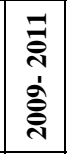 & 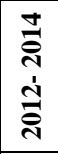 & 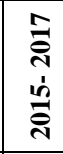 \\
\hline $\begin{array}{l}\text { Entire } \\
\text { population }\end{array}$ & 100 & 100 & 100 & 100 & 100 & 100 & 100 & 100 & 100 & 100 & 100 & 100 \\
\hline \multicolumn{13}{|c|}{ Of the total number of population aged: } \\
\hline $\begin{array}{l}\text { - younger } \\
\text { than } \\
\text { working age }\end{array}$ & 39.76 & 38.82 & 29.86 & 28.59 & 23.27 & 24.48 & 18.14 & 17.19 & 16.23 & 16.05 & 16.07 & 16.15 \\
\hline $\begin{array}{l}\text { - at working } \\
\text { age }\end{array}$ & 51.61 & 52.52 & 58.37 & 55.99 & 60.37 & 56.96 & 61.27 & 62.5 & 62.95 & 62.83 & 62.35 & 61.89 \\
\hline $\begin{array}{l}\text { - older than } \\
\text { working age }\end{array}$ & 8.57 & 8.64 & 11.76 & 15.38 & 16.33 & 18.5 & 20.51 & 20.39 & 20.82 & 21.11 & 21.58 & 21.96 \\
\hline $\begin{array}{l}\text { Urban } \\
\text { population }\end{array}$ & 17.75 & 33.49 & 52.42 & 62.05 & 69.09 & 73.43 & 73.31 & 73.36 & 73.32 & 73.42 & 73.56 & 73.67 \\
\hline \multicolumn{13}{|c|}{ Of the total number of population aged: } \\
\hline $\begin{array}{l}\text { - younger } \\
\text { than } \\
\text { working age }\end{array}$ & 5.53 & 10.5 & 14.22 & 15.7 & 15.17 & 17.48 & 12.41 & 11.86 & 11.3 & 11.19 & 11.19 & 11.25 \\
\hline $\begin{array}{l}\text { - at working } \\
\text { age }\end{array}$ & 10.96 & 20.69 & 32.87 & 37.77 & 43.74 & 43.27 & 46.33 & 46.93 & 46.9 & 46.82 & 46.52 & 46.23 \\
\hline $\begin{array}{l}\text { - older than } \\
\text { working age }\end{array}$ & 1.25 & 2.29 & 5.33 & 8.56 & 10.16 & 12.64 & 14.5 & 14.57 & 15.12 & 15.42 & 15.84 & 16.18 \\
\hline $\begin{array}{l}\text { Rural } \\
\text { population }\end{array}$ & 82.25 & 66.51 & 47.58 & 37.95 & 30.91 & 26.57 & 26.69 & 26.72 & 26.68 & 26.58 & 26.44 & 26.33 \\
\hline \multicolumn{13}{|c|}{ Of the total number of population aged: } \\
\hline $\begin{array}{l}\text { - younger } \\
\text { than } \\
\text { working age }\end{array}$ & 34.23 & 28.32 & 15.64 & 12.89 & 8.1 & 7.01 & 5.72 & 5.33 & 4.93 & 4.87 & 4.87 & 4.9 \\
\hline $\begin{array}{l}\text { - at working } \\
\text { age }\end{array}$ & 40.65 & 31.83 & 25.51 & 18.22 & 16.63 & 13.69 & 14.94 & 15.57 & 16.05 & 16.01 & 15.83 & 15.65 \\
\hline $\begin{array}{l}\text { - older than } \\
\text { working age }\end{array}$ & 7.32 & 6.34 & 6.43 & 6.82 & 6.17 & 5.86 & 6.01 & 5.82 & 5.71 & 5.7 & 5.73 & 5.77 \\
\hline
\end{tabular}


Analyzing the distribution of the population by age groups (table II), it can be noted that in Russia there are social processes similar not only to European States, but also to all economically developed countries (USA, Canada, Japan, China, etc.): urbanization and population aging. And if urbanization is a social project of the governments of almost all countries in the transition from an agrarian social order to an industrial one, population ageing - the "unpleasant" and, to put it mildly, an unintended consequence of industrialization and improve the quality of life (improved medical care, increased life expectancy and the level of social benefits to the average individual)The problems of migration in modern society acquire a geopolitical nature, including bearing threats to national security [29].

Analyzing the statistics of migration processes for the last 27 years (from 1990 to 2017 inclusive) we note its positive dynamics:

1) Studying the dynamics of migration growth of the Russian population, it can be noted that the average growth rate of this indicator for the considered 27 years was $110 \%$. However, the dynamics does not allow to speak about its stable character: it is possible to allocate years when it made more than $200 \%$ (for example, in $1994=233 \%$, in $2005=$ $260 \%$, in $2011=202 \%$ ), but there were also periods when it hardly rose above 50\% (for example, $2001=34 \%, 2003=$ $50 \%$ ). It speaks about a set of factors of foreign and domestic policy both of Russia, and foreign countries from which there is an "import of the labor capital", and also about the subjective and objective reasons influencing the decision of the concrete person to change a residence.

2) Comparing the percentage of internal and external migration, attention is drawn to:

- unfortunately, since 2005, the Federal state statistics service is no longer interested in the problems of movement of citizens within Russia. This was due to the high cost of collecting this information and its large " relative inaccuracy»;

- only in the first two years of the analyzed period (in 1990 and 1991) internal migration exceeded the size of external migration (in 1990, the share of internal migration population growth was $59.71 \%$, and in 1991 $92,64 \%$. In the years following 2005, the average proportion of internal migration compared to external migration was only $10.5 \%$.

3) The analysis of international migration, based on official data of the Federal state statistics service for the period 1990-2017 (2018), shows that the collapse of the Soviet Union and the actual consolidation as a place of residence of the area (region, country), where at the beginning of the perestroika process lived the bulk of the country's population, "raised from their homes" (set in motion) large migration groups. And if in the 90 s of the XX century the main "motivating force" was the "Exodus to the homeland", the migration processes of the first 18 years of the XXI century are mainly characterized by economic reasons.
4) During the whole study period, the ratio remains approximately the same for the two main groups of countries from which migrants arrive in the Russian Federation: $\approx 87$ $89 \%$ from the CIS countries and $\approx 10-13 \%$ from abroad. Moreover, the "main supplier" of labor are: Uzbekistan (depending on year: from 10 to $24.5 \%$ of the total number of migrants, with an average of $17.4 \%$ ), Tajikistan (8 to $10.6 \%$, with an average of $9.5 \%$ ), Armenia (from 7.5 to $10.6 \%$, with an average of $8.5 \%$ ), Kazakhstan (from 10,22 to $14.5 \%$, with an average of $11.4 \%$ ), Ukraine (from 11,4 to $32.2 \%$, on average - gives 19,03\%). This should take into account not only the economic but also the demographic situation of each country-the "donor of labor". Small Armenia with a population of 3.0-3.1 million people. it is much more difficult to supply the Russian labor market from 7.5 to $10.6 \%$ annually, compared to Uzbekistan with its constantly growing population (for example: from 27.3 million people in 2008 to 31.8 million people in 2016.). It should also be noted that after the events of 2014, the migration flow from Ukraine increased by 1.75 times in 2014 from $11.41 \%$ to $19.97 \%$ to $31-32$. $4 \%$ on average of the annual total migration flow. The smallest share belongs to Turkmenistan (on average-1.2\% of the total share of arrivals in the Russian Federation).

The age-sex composition of the arrivals suggests that for the period from 2000 to 2018, the main share of them:

a) "settles" in cities (on average $\approx 71.2 \%$ ). Moreover, the share of those who prefer to settle and look for work in cities among those coming from foreign countries is higher: on average for the period under review, it is $\approx 78.2 \%$.

b) accounts for the population of working age (it is on average $72.6 \%$ of the total volume of all migrants for the analyzed period). Thus, the coefficients of the total and pension burden of arriving migrants is low and averages for $2000-2018$ respectively $37.7 \%$ (total load factor) and $14.07 \%$ (pension load factor), which allows to "rejuvenate" the population of the country. It should be noted that there is a tendency to increase the proportion of children and adolescents in the total number of visitors. 
TABLE III. THE RATIO OF THE TOTAL AND PENSION BURDEN IN RUSSIA FOR THE PERIOD 1926 - 2017

\begin{tabular}{|c|c|c|c|c|c|c|c|c|c|c|c|c|}
\hline $\begin{array}{c}\text { Year } \\
\text { Indicators }\end{array}$ & 气ั & ڤે & ลू & م) & ลิ & ஓे & 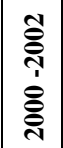 & 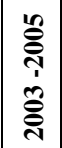 & 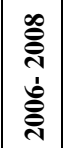 & 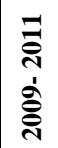 & 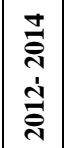 & 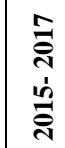 \\
\hline \begin{tabular}{|l|} 
Entire \\
population
\end{tabular} & 100 & 100 & 100 & 100 & 100 & 100 & 100 & 100 & 100 & 100 & 100 & 100 \\
\hline \multicolumn{13}{|c|}{ Country population (total) (since 2000 - averaged over 3 years): } \\
\hline $\begin{array}{l}\text { total load } \\
\text { factor }\end{array}$ & 0.937 & 0.904 & 0.713 & 0.785 & 0.656 & 0.755 & 0.631 & 0.601 & 0,589 & 0.616 & 0.665 & 0.739 \\
\hline $\begin{array}{l}\text { - retirement } \\
\text { ratio }\end{array}$ & 0.166 & 0.164 & 0.202 & 0.275 & 0.27 & 0.325 & 0.335 & 0.326 & 0.331 & 0.355 & 0.384 & 0.426 \\
\hline \multicolumn{13}{|c|}{ Urban population (since 2000 - averaged over 3 years): } \\
\hline $\begin{array}{l}\text { - total load } \\
\text { factor }\end{array}$ & 0.619 & 0.618 & 0.595 & 0.642 & 0.579 & 0.696 & 0.581 & 0.563 & 0.563 & 0.593 & 0.64 & 0.713 \\
\hline $\begin{array}{l}\text { - retirement } \\
\text { ratio }\end{array}$ & 0.114 & 0.111 & 0.162 & 0.227 & 0.232 & 0.292 & 0.313 & 0.311 & 0.322 & 0.35 & 0.379 & 0.418 \\
\hline \multicolumn{13}{|c|}{ Rural population (since 2000 - averaged over 3 years): } \\
\hline $\begin{array}{l}\text { - total load } \\
\text { factor }\end{array}$ & 1.022 & 1.089 & 0.865 & 1.082 & 0.858 & 0.94 & 0.785 & 0.716 & 0.662 & 0.682 & 0.738 & 0.818 \\
\hline $\begin{array}{l}\text { - retirement } \\
\text { ratio }\end{array}$ & 0.18 & 0.199 & 0.252 & 0.375 & 0.371 & 0.428 & 0.402 & 0.373 & 0.355 & 0.369 & 0.402 & 0.453 \\
\hline
\end{tabular}

In table III, we calculated the coefficients of the total and pension burden on the working population of the country for almost a century.

As can be seen from the analysis of the data, the pension burden on the working population for almost a century of research has increased almost 2.5 times $(42.6 \%$ for the period 2015-2017 compared to $16.6 \%$ in 1926). Moreover, for the first 18 years of the current (XXI) century, the growth rate of the pension load coefficient increased almost 2.3 times, and the coefficient itself averaged 0.426 for the period 2015-2017. I. e. on 1 working citizen of the country there are 0,426 pensioners. There is a serious imbalance in the age structure of the population, which entails an increase in social benefits.

\section{CONCLUSION}

According to the forecasts of the Government of the Russian Federation, the decline in the birth rate, the increase in life expectancy, the retirement of a large generation of 50ies, as well as the decline in the working age population by almost $14 \%$ over the next 35 years will contribute to the aging of the population in Russia. In the absence of changes in the level of economic activity of the population, the labor resources of Russia may be reduced by more than 20 million workers, and the coefficient of demographic load will grow by more than $50 \%$ [6].

The analysis of demographic indicators of Russia allowed to carry out an assessment of features of sex and age structure of the population at the present stage and in the future. At the same time, the reduction of the working-age population of the country and the aging of the population were identified as the main trend. At the same time, migration processes, which include Russia, allow in recent years to "mitigate" the consequences of the growth of the coefficient of pension burden of the population.
An increase in the share and number of representatives of the older generation in the population structure of Russia, a decrease in the number of working-age people require the government to develop a set of measures to reduce the effects of demographic aging, maintain sustainable socio-economic development and ensure a decent quality of life for older people, as well as promote active old age, which suggests maintaining workers' productive employment for longer periods.

\section{REFERENCES}

[1] M. Tolts, "A Forgotten Forerunner of Demographic Transition Theory: A Commentary", Population and Development Review (New York), 2019, vol. 45, no. 2, pp. 421-42.

[2] United States Demographics Profile 2018 - IndexMundi [Electronic resource]. Available at: https://www.indexmundi.com/united_states /demographics_profile.html.

[3] Estimates of US Population by Age and Sex - Census Bureau [Electronic resource]. Available at: http://www.census.gov/ newsroom/press-releases/2018/pop-characteristics.html.

[4] R. Ehrlich Paul, "Collapse of civilization is a near certainty within decades" [Electronic resource]. Available at: https://www.theguardian.com/cities/2018/mar/22/collapse-civilisationnear-certain-decades-population-bomb-paul-ehrlich.

[5] V. G. Dobrokhleb and V. N. Barsukov, "Demograficheskiye teorii i regional'nyy aspektstareniya naseleniya", Ekonomicheskiye i sotsial'nyye peremeny: faktory, tendentsii, prognoz, 2017, T.10, no. 6 , pp. 89-103. DOI: 10.15838/esc.2017.6.54.6.

[6] R. G. Yemtsov and A. Posharats, "Stareniye naseleniya, dostizheniye natsional'nykh tseley razvitiya $\mathrm{i}$ vyzovy $\mathrm{v}$ sfere zdravookhraneniya $\mathrm{i}$ demografii: Rossiya $\mathrm{v}$ global'nom [Electronic resource]. Available at: Novye-vyzovy-v-sotsialnoy-sfere_obespechivayushchie-dostizhenienatsionalnykh-tseley-razvitiya-Rossiyskoy-Federatsii-do-2024-goda-vsfere-demografii-i-zdravookhraneniya-_1

[7] T. Mal'tus, "Opyt zakona o narodonaselenii", per. s angl. I.A. Vernera, M.: Tipolitografiya O.I. Lashkevich, 1895, 250 p.

[8] K. Marks and F. Engel's, "Sochineniya", 2-ye izd., M.: Gosudarstvennoye izdatel'stvo politicheskoy literatury, 1955, T. 23, 920 p.

[9] L.L. Rybakovskogo, "Prakticheskaya demografiya: uchebnoye posobiye dlya vuzov", M.: TSSP, 2005, 280 p.

[10] E. Rosset, "Protsess stareniya naseleniya", M.: Statistika, 1968, 508 p.

[11] A. Sovi, "Obshchaya teoriya naseleniya. T. 2: Zhizn' naseleniya", per. s frants. F.R. Okunevoy, M.: Progress, 1977, 520 p.

[12] A. La Landry and A. Girard, "Révolution Démographique", INED, $1982,230 \mathrm{p}$.

[13] W. S. Thompson, "Population. American Journal of Sociology", 1929, no. 34 (6), pp. 959-975.

[14] F. W. Notestein, "Population. The Long View", Food for the World, University of Chicago Press, 1945. pp. 35-57.

[15] N. B. Barkalov, "Modelirovaniye demograficheskogo perekhoda", M.: Izdatel'stvo Moskovskogo universiteta, 1984, $80 \mathrm{p}$.

[16] A. G. Vishnevskiy, "Vosproizvodstvo naseleniya i obshchestvo: Istoriya, sovremennost' i vzglyad v budushcheye", M.: Finansy i statistika, 1982, $287 \mathrm{p}$.

[17] D. Reer, "Ekonomicheskiye i sotsial'nyye posledstviya demograficheskogo perekhoda", Demograficheskoye obozreniye, 2014, no. 4 [Electronic resource]. Available at: http:// demreview.hse.ru/2014-4/150230090.html.

[18] M.A. Klupt, "Paradigmy i oppozitsii sovremennoy demografii", Demograficheskoye obozreniye, 2014, no. 1 [Electronic resource]. Available at: https://demreview.hse.ru/data/2014/07 /15/1312457289/2. 
[30] "Federal'naya sluzhba gosudarstvennoy statistiki", Ofitsial'naya statistika, Naseleniye, Demografiya [Electronic resource]. Available at: http://www.gks.ru/wps/wcm/connect/rosstat_main/rosstat/ru/ statistics/population/demography.

[31] "Demograficheskiy yezhegodnik Rossii 2002", Stat. sb., Goskomstat Rossii, M., 2002, 397 p.

[32] "Demograficheskiy yezhegodnik Rossii 2008", Stat. sb., Goskomstat Rossii, M., 2008, 557 p.

[33] "Demograficheskiy yezhegodnik Rossii 2013", Stat.sb., Rosstat.-M., 2013, 543 p.

[34] "Demograficheskiy yezhegodnik Rossii 2017", Stat.sb., Rosstat.-M., 2017, section 1, cl. 12, Urban population, rural population [Electronic resource]. Available http://www.gks.ru/free_doc/new_site/population/demo/demo11.xls.

[35] "Demograficheskiy yezhegodnik Rossii 2017", Stat.sb., Rosstat.-M., 2017, section 1, cl. 13, Distribution of the population by sex [Electronic resource]. Available at: http://www.gks.ru/free_doc/ new_site/population/demo/demo13.xls.

[36] "Demograficheskiy yezhegodnik Rossii 2017", Stat.sb., Rosstat.-M., 2017, section 1, cl. 14, Age distribution of population [Electronic resource]. Available at: http://www.gks.ru/free_doc/new_site/ population/demo/demo14.xls.

[37] "Demograficheskiy yezhegodnik Rossii 2017", Stat.sb., Rosstat.-M., 2017, section 2, 21 p., Natural increase, the ratio of births and deaths [Electronic resource]. Available at: http://www.gks.ru/free_doc/ new_site/population/demo/demo21.xls.

[38] "Demograficheskiy yezhegodnik Rossii 2017", Stat.sb., Rosstat.-M., 2017, section 7, Migration of the population [Electronic resource]. Available at: http://www.gks.ru/free_doc/new_site/population/ demo/demo7.xls.

[39] "Demograficheskiy yezhegodnik Rossii 2017", Stat.sb., Rosstat.-M., 2017, section 9, International comparisons.

[29] N.G. Privalov, "Tretiy put' Rossii: novaya nadezhda v KHKHI veke", Yekaterinburg: Ural'skoye izd-vo, 2012. 